\title{
IMPACT OF BEHAVIOURAL BIASES IN CHOOSING INVESTMENT AVENUES: AN EMPIRICAL STUDY
}

\author{
Rachit Agarwal \\ Assistant Professor, \\ Sunder Deep College of Management \& Technology, \\ Ghaziabad-Delhi NCR
}

Article DOI: https://doi.org/10.36713/epra6687

\begin{abstract}
The behaviour of an individual investor is expansively influenced by different biases that came into limelight in the rising regulation of behaviour finance. In finance, behavioural finance is the latest regulation that studies the cognitive psychology of the decisions that are taken by an individual related to money. The theory of standard economic had evolved this in its response and it has the ability to presume that people are sensible, prefers low risks investments and maximises their profits. In real time scenario it is seen that people are not that sensible when they make their decisions during the investment process. There are different behavioral biases factors that influence the investors while choosing their investment avenues. The objective of the study is to know the behavioural factors that affect the decision of the Investors and their impact on the investor in choosing the investment avenues. A sample of 273 respondents were taken in which Investors from different sector were surveyed with the help of standard questionnaire. Mean and test was used to get appropriate results. It is found that there are different behavioral factors such as mood, emotional, heuristic, personality and overconfidence that influence the investors while making his investments and all the behavioural biases has a significant impact on the process of choosing the investment avenues.
\end{abstract}

KEYWORDS: Behavioural Biases, Behavioural Finance, Investment Avenues, Investors.

\section{INTRODUCTION}

The market of finance is considered to be a market where the futures are secured and in which the funds for long term are raised by the private and government companies. It is designed to sell and buy the bonds and stocks. In the economy market of India, long terms saving avenues are provided by the institutions of financial market that use to mobilize and channelize into investments. For the country's economic growth, confidence of the retail investor plays a very important role in the market. The market is perfectly predicted, the flexible process of the stocks is identified by the behavioural finance and it also helps to know the other player's behaviour that are accessing in the market. Behavioural finance is a latest concept of the theory of finance that seeks to know and make predictions of the implications of psychological process of making decisions of the systematic financial market.

There are different behavioural factors that had their impact on the investment decision of an investor. "Mood", "emotions", "heuristics", "frames", "personality" and "gambling". Studies revealed that these behavioural factors have a significant influence on the investment decisions of $\mathrm{n}$ investor. The aftermath of the impact of the interdependency of these behavioural bias factors with each other revealed that, beside the factor "mood", rest of the behavioral factors shares a strong relation with each other (Charles and Kasilingam, 2016).

\section{Behavioural factors that affect the}

investor's decision are discussed below:

The effects of "Overconfidence" are presented strongly in the decisions that are really tough; uncertainty is included in that process. Therefore, it is seen that overconfidence very likely affects the making of financial decisions. The cases where the decisions are made on the basis of the superficial characteristics of the situation instead of the real situation with all the evaluated details the idea or concept of "Representativeness bias" is reflected there. It can also be explained in another way, the representativeness bias is reflected where the decisions are made on the basis of stereotypes. The predisposition of individual to attribute their own success to any natural aspect like "talent" or foresightedness" is referred by Self serving 
attribution bias or "Self attribution". These kinds of individuals also blames outside influences for their failures, like bad luck. "Loss aversion" mentions the conception when the investor is suffering through huge disutility from the loss of money and prosperity than the efficacy from an almost equal gain of wealth in terms that are complete and absolute. Therefore, the risks are increased by the investors, defining it in terms of doubt and indecision so that he can avoid the least chance of loss. In the case of investments, it is suggested by "Confirmation bias" that the individual that is investing will probably look for the details that is supporting his or her idea which is original regarding an investment instead of seeking out for the details that challenge or oppose it. The tendency of an individual to focus on new and latest behaviour and giving little weight age to trends that are there from the longer period of time is described by "Anchoring". There are people that are inclined to give more weight age to the latest experiences; they are more likely to extrapolate the latest trends that are more frequent at chances with average and probability for longer run. The mental procedure in which an individual stick to his or her previous opinions and views or had to tendency of forecasting at the cost of acknowledgment to new details is known as "Conservatism bias". Due to this it is possible that investors started under reacting to these new details, he may start maintaining imitations that is copied from the earlier estimations instead of taking actions on the latest details. It is suggested "Availability bias" that the investment decisions of the investors are more influenced by the recent memory, which mean that he is more influenced by the examples that are available at that time. In this condition he will not invest in that avenues those are showing loss in recent days. If the investors had seen the crisis in the stock market in some recent days, he had the tendency and fear at the same time to not to invest those markets.

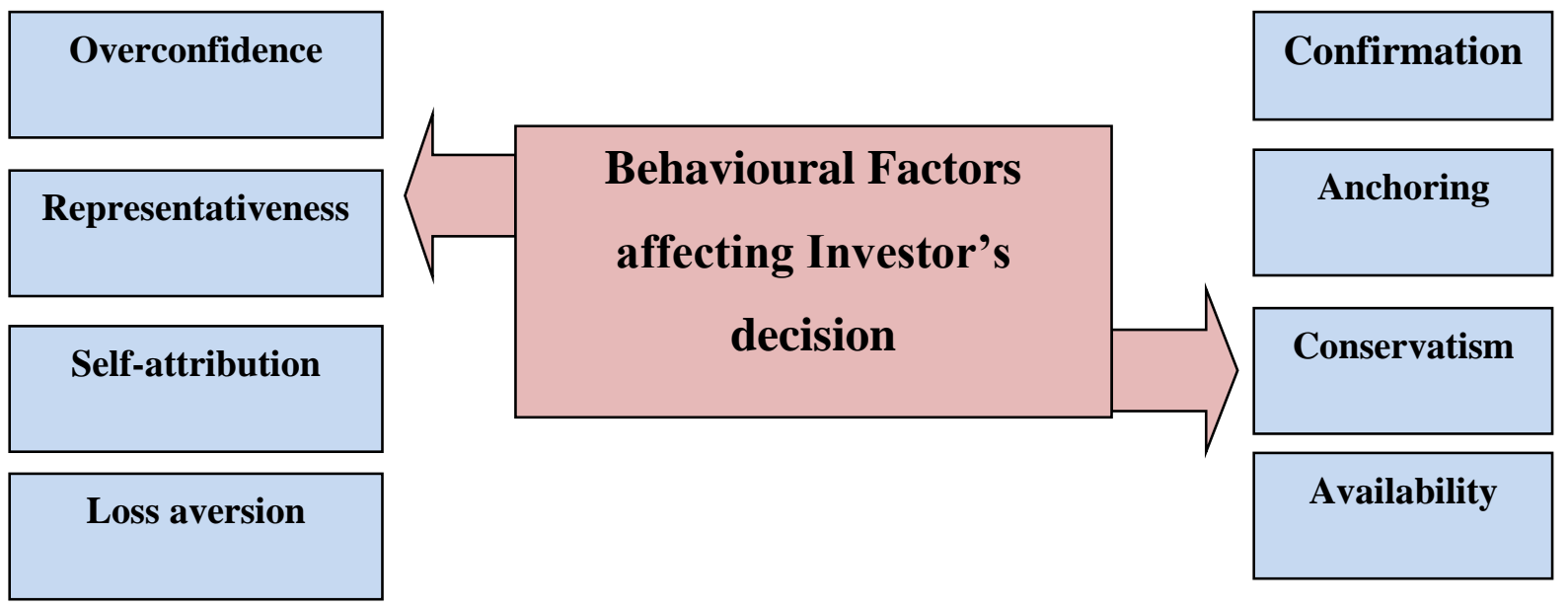

Figure: Behavioural Factors affecting Investor's decision

It is seen that in the market of Asia, the effect of the herding is more profound and at the time when the market is rising the asymmetry in their herding is also seen. In addition, it was witnessed that at the time of crisis in the whole worlds the markets of United States and Latin America are showing the presence of herding. The studies shows that the herding of the bank gets diverge with various kinds of loans. It is analysed that in comparison to any other kind of loans herding is more frequently found in the loans taken for house, property and credit cards. Furthermore, it is found that the in comparison to regional and small banks herding is found more in the bigger banks (Tran, Nguyen, \& Lin, 2017). The presence of "herding" behaviour is investigated in a study amid the stock market and market of oil at the time of market distress. The investigators found that when the volatility of the stock market increases the herding behaviour is automatically reduced. It is also analysed and it also occurs that there is inverse movement of herding behaviour in both the markers and the at the same time it is also seen that herding behaviour is enhanced more due to the unavailability of the details and information in both stock and oil market (Ben Mabrouk, 2018). There are so many insights that are offered by behavioural finance for the professional of investment and therefore, framework is also provided to evaluate the strategies for active investment for the ones that invests in the market. All over the world the capital market is growing and expanding every day. For each and every state and country it is very important to attract the capital so that their growth is increased and to raise the capital that is necessary the best route to choose is capital market. Each and every investor has its important role in the capital market and due to this it is necessary to know the individual investor's behaviour so that their perception can be easily 
managed and, in that way, volatility of the market can be easily controlled (Thomas, 2018).

\section{LITERATURE REVIEW}

To achieve the financial goals, the knowledge of past experience is very necessary and on the basis of that knowledge and experiences the course of future investment actions should be taken instead of depending on the previous experiences and keep on making the mistakes due to their stay on inflexible behaviour to not adopt the latest dynamic situations of investments. On the other the hand the previous experiences are good teachers that teach positive aspects of investing to their investors that can be used to achieve financial targets by making correct decisions of the investments. The decisions of investment are prevalent economic condition dependent and it also depends on the ambiance for the avenues of the investment. Despite of the fact that the financial and investment targets of an individual are subjective in nature, they had a great effect of behavioral biases (Chopde and Kulkarni 2017). Behavioral biases like "Over confidence bias", "Representative Bias", "Self-attribution bias", "loss aversion bias", "Fear of regret/ regret avoidance", "confirmation bias", "Anchoring bias" and "Conservatism bias" were studied and it is seen that there is no significant difference amid the investor's professional status relating to behavioral biases. It is also found that except "anchoring biases" all these biases have no significant difference amid the change in pattern of their profession. As this unresponsiveness is because of psychological behaviour and this is personal also for every investor, it changes from individual to individual and there is no change in them due the change in profession (Jenica, 2018)

Madaan and Singh (2019) studied the influence of behavioural biases on the process of making the decisions for an investment of an individual. The key behavioral biases that are considered in the study are "Overconfidence", "Anchoring", "disposition effect", and "Herding". It is seen that the individual's investment decisions are highly influenced by the two behavioural biases "overconfidence" and "herding". It is also found that the ones that are taking part in the financial markets are not rational in their process of making the decisions and they had restricted choices also. Vishnoi (2015) concluded that there is significant impact of behavioral biases on the decisions of an investor. It is also seen that there is less number of female investors as compared to male investors and the investors that belong to the age group 26-45 are more active as compared to any other age group. Majority of investors had an experience of about five to ten years of investment and others are having of less than five years. Rs. 50000-1 lakh is the maximum amount of investment that is invested by the investors in the stock market. The aftermath of the study says that the Gwalior city's investors are very careful regarding their investments. Therefore, the study suggests that the investors should create their portfolio before making investment and it is very important for them to learn about the different behavioural biases before making the investments.

Upadhyay and Shah (2019) found that the investors are not "rational" and the investors in more or less proportion are influenced by all the behavioural biases such as "Over confidence bias", "Representative Bias", "Self-attribution bias", "loss aversion bias", "Fear of regret/ regret avoidance", "confirmation bias", "Anchoring bias" and "Conservatism bias" during his process of making the investment decisions. Singh and Yadav (2016) studied that there are so many considerations like "tax planning", "future needs", "safety of investments" and "recurring income" that need to be considered while making the investments. Therefore it is necessary and also required by all the investors to consider these important variables while making investment decisions so as to get good returns. Muneeswaran, Babu and Gayathri (2019) found that investors from the urban and non urban areas had different risk attitude and awareness related to different avenues of investment. It is seen that marital status does not affect their level of awareness but their age difference and educational profile influences their risk attitude and risk level that they are facing is different for every individual investor. It is concluded in the study that the knowledge, investment options and risk level of any investment is provided to the investor with the help of recent technologies. Sarkar and Sahu (2018) found that there is moderate level of awareness among the investors and there financial awareness is more as compared to social learning. The attitude of perceived risk is majorly guided by "Affect" instead of "Cognition". It is indicated by analysis done during the study that the "Investment Behaviour" of the investor of a stock market is significantly influenced by the "Demographic Factor", "Awareness" and "Attitude of Perceived Risk". Isidore and Christie (2018) studied that lower "overconfidence bias" is more likely to be exhibited by the investors that has low annual income but high "Representativeness", "Loss aversion", "Availability" and "Mental accounting" biases. These investors with low annual income are more prone to show the signs of biases since they don't have enough money to get better advice on finance, lack of awareness and knowledge etc. It is suggested that the investors with low annual income should take the advice from the financial advisors and managers according to their situation of being prone to behavioural biases. Rehan and Umer (2017) have indicated through their study that some behavioural 
biases have a deep and philosophical effect on the decisions that are made by the investors. It is constantly seen in other studied also that there is a positive impact of "Anchoring", "Risk aversion", "Overconfidence", "Representativeness" and "Regret aversion" behavioural biases on the investment decisions of the investors. Raheja and Dhiman (2019) found that "Risk tolerance" and "Overconfidence" bias and "Regret bias" share a relation. While making an investment, the investors think that he is making all the correct decisions related to that investment and go ahead to take the risk. The relation amid decision for investment and "overconfidence bias" and "regret bias" is also found and therefore, investment decisions can be better explained by behavioural biases with the help of "Risk tolerance".

\section{OBJECTIVE OF THE STUDY}

1. To find the behavioural factors that affects the decision of the Investors to choose the Investment Avenues.

2. To find the Impact of behavioural bias in choosing Investment Avenues.

\section{METHODOLOGY AND SAMPLING DESIGN}

The present study is done by conducting a survey in which a standard questionnaire was distributed to collect the data. A sample of 273 respondents were taken in which Investors from different sector with different occupational profile were considered. The study is empirical in nature and sampling is convenience sampling. The people were survey to know about the behavioural factors that affects their decision in choosing the investment avenues and their impact on the investor while choosing their investment avenues. Mean and t test was used to get appropriate results.

\section{FINDINGS OF THE STUDY}

Table 1 demonstrates the Demographic Profile of the Respondents in which the surveyed people had asked about their gender, age group, qualification, profession and monthly income. In the total number of 273 respondents $61.9 \%$ are male and $38.1 \%$ are female in which $17.9 \%$ belongs to the age group 21 30 years, $19.4 \%$ are from the age group $31-40$ years, $22.3 \%$ and $21.6 \%$ are from the age group $41-50$ years and $51-60 \%$ respectively and $18.7 \%$ are above 60 years of age. Among them $19.4 \%$ are undergraduates, $25.3 \%$ are graduates, $26.7 \%$ are postgraduates and the rest $28.6 \%$ had some other degrees as their qualification. $35.5 \%$ are businessmen, $31.5 \%$ are from the service sector and $33 \%$ are retired from their job. $15.0 \%$ are earning Rs. 15,000-25,000 per month, $17.9 \%$ earns Rs. 26,000-35,000 every month and $20.9 \%$ had an income of Rs. $36,000-45,000,22.3 \%$ are earning 46,000-55,000 per month and the rest $23.8 \%$ had a monthly income of Above Rs. 55,000.

Table 1 Demographic Profile of the Respondents

\begin{tabular}{|c|c|c|}
\hline Variables & No. of respondents & \%age \\
\hline Gender & 169 & $61.9 \%$ \\
\hline Male & 104 & $38.1 \%$ \\
\hline Female & $\mathbf{2 7 3}$ & $\mathbf{1 0 0 \%}$ \\
\hline Total & & $17.9 \%$ \\
\hline Age groups & 49 & $19.4 \%$ \\
\hline $21-30$ years & 53 & $22.3 \%$ \\
\hline $31-40$ years & 61 & $21.6 \%$ \\
\hline $41-50$ years & 59 & $18.7 \%$ \\
\hline $51-60$ years & 51 & $\mathbf{1 0 0 \%}$ \\
\hline Above 60 years & $\mathbf{2 7 3}$ & $19.4 \%$ \\
\hline Total & & $25.3 \%$ \\
\hline Qualification & 53 & $26.7 \%$ \\
\hline Under graduate & 69 & $28.6 \%$ \\
\hline Graduate & 73 & $\mathbf{1 0 0 \%}$ \\
\hline Post graduate & 78 & $35.5 \%$ \\
\hline Others & $\mathbf{2 7 3}$ & $31.5 \%$ \\
\hline Total & & $33 \%$ \\
\hline Profession & 97 & $\mathbf{1 0 0 \%}$ \\
\hline Business man & 86 & $15.0 \%$ \\
\hline Service man & 90 & $\mathbf{2 7 3}$ \\
\hline Retired & & \\
\hline Total & 41 & \\
\hline Monthly Income (Rs.) & & \\
\hline 15,000-25,000 & & \\
\hline & & \\
\hline
\end{tabular}




\begin{tabular}{|c|c|c|}
\hline $26,000-35,000$ & 49 & $17.9 \%$ \\
\hline $36,000-45,000$ & 57 & $20.9 \%$ \\
\hline $46,000-55,000$ & 61 & $22.3 \%$ \\
\hline Above 55,000 & 65 & $23.8 \%$ \\
\hline Total & $\mathbf{2 7 3}$ & $\mathbf{1 0 0} \%$ \\
\hline
\end{tabular}

Table 2 Behavioural bias factors in choosing Investment Avenues

\begin{tabular}{|c|c|c|c|c|}
\hline $\begin{array}{l}\text { SI. } \\
\text { No. }\end{array}$ & Behavioural bias factors in choosing Investment Avenues & $\begin{array}{l}\text { Mean } \\
\text { Value }\end{array}$ & $\begin{array}{c}\mathrm{t} \\
\text { Value }\end{array}$ & Sig \\
\hline & Mood & & & \\
\hline 1. & My market activities are influenced by my happy mood & 3.53 & 9.52 & 0.00 \\
\hline \multirow[t]{2}{*}{2.} & My market behaviour is affected by my physical tiredness & 3.97 & 14.44 & 0.00 \\
\hline & Emotional & & & \\
\hline 3. & $\begin{array}{l}\text { I get confused for future investment when I face constant loss in my } \\
\text { investment }\end{array}$ & 4.01 & 16.98 & 0.00 \\
\hline \multirow[t]{2}{*}{4.} & $\begin{array}{l}\text { I am encouraged with my positive attitude to invest more in the } \\
\text { market even after a deep fall }\end{array}$ & 4.13 & 18.09 & 0.00 \\
\hline & Heuristic & & & \\
\hline 5. & To invest in already known stocks is my preference & 3.93 & 13.47 & 0.00 \\
\hline \multirow[t]{2}{*}{6.} & I prefer to buy the stocks that had less risks & 3.76 & 13.65 & 0.00 \\
\hline & Personality & & & \\
\hline 7. & Self discipline is maintained during trading & 3.59 & 8.78 & 0.00 \\
\hline 8. & $\begin{array}{l}\text { I always try to converts my losses into gains by investing more in the } \\
\text { market and choosing different avenues }\end{array}$ & 4.11 & 18.66 & 0.00 \\
\hline \multirow[t]{2}{*}{9.} & $\begin{array}{c}\text { I feel restless when I am not able to take active participation in market } \\
\text { activities }\end{array}$ & 3.61 & 9.77 & 0.00 \\
\hline & $\begin{array}{l}\text { Overconfidence } \\
\end{array}$ & & & \\
\hline 10. & $\begin{array}{l}\text { Sometimes overconfidence leads me to the investment that has no } \\
\text { good returns }\end{array}$ & 3.89 & 12.89 & 0.00 \\
\hline
\end{tabular}

Table 2 shows the Behavioural bias factors in choosing Investment Avenues. It is seen that the activities of an investor is influenced by his mood when he says that my market activities are influenced by my happy mood with the mean score 3.53 and the investor also says that my market behaviour is affected by my physical tiredness with the mean value 3.97 . in the case of constant loss the investors are confused when he says that I get confused for future investment when I face constant loss in my investment with the mean score 4.01 but at the time according to investors positive attitude is helpful for him when he says that I am encouraged with my positive attitude to invest more in the market even after a deep fall 4.13 and he also says that he invest in already known stocks is my preference with the mean value 3.93 and I prefer to buy the stocks that had less risks with the mean value 3.76. Investors also agree to the fact that discipline is very important in this field when he says that Self discipline is maintained during trading with the mean value 3.59. Loss aversion is very important in choosing the investment avenues and the investors also says that I always try to converts my losses into gains by investing more in the market and choosing different avenues with the mean value 4.11 . Investors also say that I feel restless when I am not able to take active participation in market activities with the mean value
3.61. It is seen that positive attitude is the most significant behavioral bias factors that affects the decision making process of investment for an investor. According to investors overconfidence in choosing the investment is not good as sometimes overconfidence leads me to the investment that has no good returns with the mean value 3.89. One sample t-test was applied to find whether the responses to the statements are significant or not. It was found that for all the statements the value under significance column is below 0.05 hence, all the mean values for the statements have been found significantly more than the test values (3.5) hence all the solutions are significant.

\section{CONCLUSION}

The attention in the stock market is considered by the impact of behavioural biases on the decision taken related to any investment. Investors are suggested to create their selection and collection range while investing and had a complete knowledge of all the behavioral biases before making any investment in the market. It is seen that the there are so many factors that are considered by the investors before making their investment decision and the most important factor is behavioural biases. 
The study concluded that that there are different behavioral factors such as "mood", "emotional", "heuristic", "personality" and "overconfidence" that influence the investors while making his investments and all the behavioural biases has a significant impact on the process of choosing the investment avenues.

The explanations are provided by behavioural finance that why the irrational decisions for investment is made by the investors. It is also demonstrated by the behavioural finance that how the process of making the investment decisions is influenced by the emotions and cognitive errors and psychological and sociological factors are also implied by behavioural finance that affects the investor's decision.

\section{REFERENCES}

1. Charles A. and Kasilingam R. (2016), "Impact of Selected Behavioural Bias Factors on Investment Decisions of Equity Investors," ICTACT Journal on Management Studies, Vol. 02(02), 297-311.

2. Chopde, S. and Kulkarni, N. (2017), "Impact of Behavioral Biases on Investment Decisions of Individual Investors in Mumbai A sample study," International Conference On Emanations in Modern Technology and Engineering, Vol. 5(3), 74-77.

3. Jenica, S. (2018), "Behavioural Biases of Individual Investors," International Journal for Research in Engineering Application \& Management (IJREAM), Vol-04(03), 170-176.

4. Tran, V. T., Nguyen, H., \& Lin, C. T. (2017), "Herding behaviour in the Australian loan market and its impact on bank loan quality," Accounting and Finance, 57(4), 1149-1176.

5. Ben Mabrouk, H. (2018), "Cross-herding behaviour between the stock market and the crude oil market during financial distress: Evidence from the New York stock exchange," Managerial Finance, 44(4), 439-458.

6. Madaan, G., \& Singh, S. (2019), “An Analysis of Behavioral Biases in Investment DecisionMaking," International Journal of Financial Research, 10(4), 55.

7. Vishnoi, S. (2015), "Impact of Behavioural Biases on Investment Decision: With special Reference to Gwalior City," International Journal in Management and Social Science, Vol.03(10), 255-261.

8. Upadhyay, D. and Shah, P. (2019), "A study on behavioral finance in investment decisions of investors in Ahmadabad," International Journal of Novel Research and Development, Vol. 4(7), 103-114.

9. Thomas, T. C. (2018), "Influences of behavioural biases on retail investors - evidences from India," International Journal of Current Engineering and Scientific Research (IJCESR) Vol. 5(4), 27-36.

10. Singh, J. and Yadav, P. (2016), "A Study on the Factors Influencing Investors Decision in Investing in Equity Shares in Jaipur and Moradabad with Special Reference to Gender," Amity Journal of Finance, Vol. 1(1), 117-130.
11. Sarkar, A. K. and Sahu, T. N. (2018), "Analysis of Investment Behaviour of Individual Investors of Stock Market: A Study in Selected Districts of West Bengal," Pacific Business Review International, Vol. 10(7), 07-17.

12. Isidore R., R., \& P., C. (2019), "The relationship between the income and behavioural biases." Journal of Economics, Finance and Administrative Science.

13. Rehan, R. and Umer, I. (2017), "Behavioural Biases and Investor Decisions," Market Forces College of Management Sciences, Vol. XII (2), 12-20.

14. Raheja, S. and Dhiman, B. (2019), "Relationship between Behavioral Biases and Investment Decisions: The Mediating Role of Risk Tolerance," DLSU Business \& Economics Review, 29(1), 31-39.

15. Muneeswaran, R., Babu, M. and Gayathri, J. (2019), “Investors' Behaviour on Investment Avenues," International Journal of Engineering and Advanced Technology (IJEAT), Vol. 9(2), 2260-2263. 